\title{
Mechanisms in rabbit aorta for hyperglycaemia-induced alterations in angiotensin $I I$ and norepinephrine effects
}

\author{
D.A. Simmons and A..I. Winegrad \\ Cox Institute, Department of Medicine, University of Pennsylvania School of Medicine, Philadelphia, Pennsylvania, USA
}

\begin{abstract}
Summary. The $\left(\mathrm{Na}^{+}, \mathrm{K}^{+}\right)$-ATPase activity operative in rabbit aortic intima-media incubated with normal plasma levels of glucose and myo-inositol $(70 \mu \mathrm{mol} / \mathrm{l})$ is decreased when the glucose content of the medium is raised from 5 to $10 \mathrm{mmol} / 1$ or higher; this effect is prevented by aldose reductase inhibitors and by raising the myo-inositol content of the medium to $500 \mu \mathrm{mol} / 1$. The decrease in $\left(\mathrm{Na}^{+}, \mathrm{K}^{+}\right)$-ATPase activity results from the loss of a component normally regulated (stimulated) by endogenously released adenosine through a receptor that stimulates phosphatidylinositol turnover in a discrete pool. The replenishment of this phosphatidylinositol pool selectively requires myo-inositol transport and is inhibited when increased polyol pathway activity impairs myo-inositol transport at a normal plasma level. Adenosine is a vasodilator, some endothelium-released vasodilators modulate the responses to vasoconstrictors by stimulating an increase in $\left(\mathrm{Na}^{+}, \mathrm{K}^{+}\right)$-ATPase activity in vascular smooth muscle. Whether adenosine mediates this effect in angiotensin II or norepinephrine-stimulated aorta was examined. Angiotensin II $(100 \mathrm{nmol} / \mathrm{l})$ and norepinephrine $(1 \mu \mathrm{mol} / \mathrm{l})$ evoked
\end{abstract}

marked increases in $\left(\mathrm{Na}^{+}, \mathrm{K}^{+}\right)$-ATPase activity in aortic intima-media incubated with $5 \mathrm{mmol} / 1$ glucose and $70 \mu \mathrm{mol} / \mathrm{l}$ myo-inositol, which were inhibited when adenosine deaminase was added or the medium myo-inositol omitted to inhibit myo-inositol transport. Raising the medium glucose to $30 \mathrm{mmol} / \mathrm{l}$ inhibited the angiotensin II and norepinephrineevoked increases in $\left(\mathrm{Na}^{+}, \mathrm{K}^{+}\right)$-ATPase activity, and this was prevented when tolrestat $(10 \mu \mathrm{mol} / \mathrm{l})$ was added or the myoinositol content of the medium was raised from 70 to $500 \mu \mathrm{mol} / \mathrm{l}$. Hyperglycaemia causes decreased $\left(\mathrm{Na}^{+}, \mathrm{K}^{+}\right)$ATPase activity prevented by aldose reductase inhibitors and by raising plasma $m y o$-inositol by a mechanism which inhibits an adenosine-( $\left.\mathrm{Na}^{+}, \mathrm{K}^{+}\right)$-ATPase regulatory system, which modulates the responses to angiotensin II and norepinephrine in some blood vessels.

Key words: Aorta, $\left(\mathrm{Na}^{+}, \mathrm{K}^{+}\right)$-ATPase, adenosine, angiotensin II, norepinephrine, hyperglycaemia, vasodilation, vasoconstriction.
The vasopressor responses to i.v. angiotensin II and norepinephrine are increased in diabetic states, even when vascular complications and hyperinsulinaemia are absent, and the vasoconstrictive responses to these agonists are increased in specific arteries and arterioles in streptozotocin diabetic rats and alloxan diabetic rabbits [1-6]. Because there is no known mechanism by which hyperglycaemia could cause increased vasoconstrictive responses to angiotensin II or norepinephrine, it has received scant consideration as a possible causal factor. Vasoconstriction in arteries and resistance arterioles is normally modulated by endothelium-released vasodilators, and impaired modulation is a cause for increased vasoconstrictive responses [7]. The endothelium-derived vasodilators include a hyperpolarizing factor (or factors) of unknown structure that acts by stimulating increased electrogenic $\left(\mathrm{Na}^{+}, \mathrm{K}^{+}\right)$-ATPase activity in vascular smooth muscle $[7,8]$.
Hyperglycaemia decreases $\left(\mathrm{Na}^{+}, \mathrm{K}^{+}\right)$-ATPase activity and induces functional alterations in specific tissues by a mechanism whose identifying characteristic is that its effects are prevented in diabetic animals both by aldose reductase inhibitors and by raising their otherwise normal plasma myo-inositol (MI) levels by approximately sevenfold $[9,10]$. It was recently found that this mechanism can be activated and studied in vitro in resting normal rabbit aortic intima-media (AIM) and that it inhibits a previously unknown adenosine $\left(\mathrm{Na}^{+}, \mathrm{K}^{+}\right)$-ATPase regulatory system [11-13]. Adenosine is an autocoid that is released by most tissues in a manner that varies with their activity [14]; it is released by endothelium and is a potent vasodilator in most arteries and resistance arterioles [15, 16]. Adenosine-induced vasodilation has been ascribed to $\mathrm{A}_{2}$ receptors that stimulate adenylate cyclase in vascular smooth muscle, but current evidence suggests that this is 
not the sole or primary vasodilatory mechanism of adenosine and the existence of some other mechanism(s) has been postulated [15]. In resting AIM incubated with normal plasma levels of glucose and MI, endogenously released adenosine regulates (stimulates) a distinct component of $\left(\mathrm{Na}^{+}, \mathrm{K}^{+}\right)$-ATPase activity through a novel type of $\mathrm{A}_{2}$ receptor that stimulates rapid basal phosphatidylinositol (PI) turnover, apparently phospholipase C hydrolysis, in a discrete PI pool [12]. This PI pool is maintained by a distinct fraction of de novo PI synthesis that selectively requires MI transport at the low normal plasma MI level to prevent its rapid inhibition and the loss of the adenosine effect on $\left(\mathrm{Na}^{+}, \mathrm{K}^{+}\right)$-ATPase activity [12]. In AIM provided with medium $\mathrm{MI}$ in a normal plasma level raising the glucose level of the medium from 5 to $10 \mathrm{mmol} / \mathrm{l}$ or to $30 \mathrm{mmol} / \mathrm{l}$ selectively inhibits the adenosine-stimulated component of normal resting $\left(\mathrm{Na}^{+}, \mathrm{K}^{+}\right)$-ATPase activity within $60 \mathrm{~min}$. This inhibition is prevented by aldose reductase inhibitors and by raising the MI concentration of the medium seven-fold; it results from increased polyol pathway activity that impairs MI transport at a normal plasma level and inhibits the replenishment of the adenosine-sensitive PI pool $[11,12]$.

We examined the possibility that when AIM is stimulated by angiotensin II or norepinephrine the hyperglycaemia-inhibitable, adenosine- $\left(\mathrm{Na}^{+}, \mathrm{K}^{+}\right)$-ATPase regulatory system normally stimulates an increase in vascular smooth muscle $\left(\mathrm{Na}^{+}, \mathrm{K}^{+}\right)$-ATPase activity to modulate the contractile response.

\section{Materials and methods}

Male, white New Zealand rabbits $(2.0-2.5 \mathrm{~kg})$ were fasted overnight, sedated with diazepam $(2 \mathrm{mg} / \mathrm{kg}$ i. $\mathrm{m}$.), and $90 \mathrm{~min}$ later anaesthetized with sodium pentobarbital ( $30 \mathrm{mg} / \mathrm{kg}$ i.v.) and decapitated. The descending aorta was rapidly excised and four tubular segments of AIM, each weighing approximately $30 \mathrm{mg}$, were prepared by a method that produces AIM that is free of adventitia and retains an intact endothelium with a normal electron microscopic appearance $[17,18]$. All the media to which the aorta and AIM were exposed contained $9 \%$ clinical grade dextran (average mol. wt. 70,000) to provide the oncotic pressure that is required to preserve the normal ultrastructure and normal pattern of energy metabolism of AIM [17, 18]. The aorta was dissected in Krebs-Henseleit bicarbonate buffer [19] (which contains normal plasma concentrations of $\mathrm{Na}^{+}$and $\mathrm{K}^{+}$), $\mathrm{pH} 7.4$ at $37^{\circ} \mathrm{C}$, that contained normal rabbit plasma levels of glucose $(5 \mathrm{mmol} / \mathrm{l})$ and $\mathrm{MI}(70 \mu \mathrm{mol} / 1)$ and was continuously gassed with $5 \% \mathrm{CO}_{2} / 95 \% \mathrm{O}_{2}$.

For each experiment the four AIM segments from a single aorta were used to provide two paired samples, each comprised of duplicate AIM segments, in which $\left(\mathrm{Na}^{+}, \mathrm{K}^{+}\right)$-ATPase-mediated ${ }^{86} \mathrm{Rb}^{+} / \mathrm{K}^{+}$uptake was compared in similar medium in the absence and presence of angiotensin II $(100 \mathrm{nmol} / \mathrm{l})$ or in the absence and presence of norepinephrine $(1 \mu \mathrm{mol} / \mathrm{l})$. The method for determining $\left(\mathrm{Na}^{+}, \mathrm{K}^{+}\right)$-ATPase-mediated ${ }^{86} \mathrm{Rb}^{+} / \mathrm{K}^{+}$uptake in AIM was previously reported in detail $[11,12]$. Briefly, the individual freshly prepared AIM segments were equilibrated for $30 \mathrm{~min}$ at $37^{\circ} \mathrm{C}$ in $3 \mathrm{ml}$ of Krebs-Henseleit bicarbonate buffer continuously gassed with $5 \%$ $\mathrm{CO}_{2} /$ air that contained $9 \%$ dextran and specified concentrations of glucose and MI, in a $10 \mathrm{ml}$ Erlenmeyer flask in a metabolic shaker set at 88 cycles per min. The individual AIM segments were then transferred to fresh medium of the same composition that contained an added tracer quantity of $\left[{ }^{3} \mathrm{H}\right]$ sucrose. Ouabain $(0.2 \mathrm{mmol} / \mathrm{l})$ was added to one of the duplicate AIM segments in each paired sample, and the tissues pre-incubated for $10 \mathrm{~min}$, as described for the equilibration. At the end of the pre-incubation a tracer quantity of $\left[{ }^{86} \mathrm{Rb}^{+}\right] \mathrm{RbCl}$ was added to each flask, the vasoconstrictor whose effect was to be examined was added to the two AIM segments in one of the paired samples, and the tissues incubated for $20 \mathrm{~min}$. At the end of the incubation the individual AIM segments were rapidly removed, drained on filter paper, weighed, and transferred into $2 \mathrm{ml}$ of Protosol in a glass liquid scintillation vial and digested for $16 \mathrm{~h}$. The tissue digest was decobrized with $\mathrm{H}_{2} \mathrm{O}_{2}$, Econoflor 2 added to the vial, and the sample counted for ${ }^{86} \mathrm{Rb}^{+}$and ${ }^{3} \mathrm{H}$ in a liquid scintillation spectrometer with an external standard. A sample of the incubation medium was also counted and the medium $\left[\mathrm{K}^{+}\right]$determined. The ${ }^{86} \mathrm{Rb}^{+}$-counts recovered in the tissue digest were corrected for the ${ }^{86} \mathrm{Rb}^{+}$-counts trapped in the extracellular fluid in the tissue sample by means of the $\left[{ }^{3} \mathrm{H}\right]$ sucrose-counts recovered in the tissue digest and the ratio of ${ }^{86} \mathrm{Rb}^{+}$-counts/ $\left[{ }^{3} \mathrm{H}\right]$ sucrose-counts in the incubation medium. The resulting estimate of intracellular ${ }^{86} \mathrm{Rb}^{+}$-counts was expressed as $\mu \mathrm{mol}^{86} \mathrm{Rb}^{+} / \mathrm{K}^{+}$uptake $\cdot \mathrm{g}^{-1} \cdot 20 \mathrm{~min}^{-1}$ by means of the ratio of the medium $\mathrm{K}^{+}$concentration to the medium ${ }^{86} \mathrm{Rb}^{+}$counts per unit volume. The difference between the uptakes in the absence and presence of ouabain in the two AIM segments in each paired sample was used as an estimate of the $\left(\mathrm{Na}^{+}, \mathrm{K}^{+}\right)$-ATPasemediated ${ }^{86} \mathrm{Rb}^{+} / \mathrm{K}^{+}$uptake.

The sources of the materials used were: dextran, ouabain, angiotensin II, norepinephrine bitartrate (Sigma Chemical Co., St.Louis, Mo. USA); myo-inositol (Pfhanstiehl Labs. Inc., Waukegan, Ill., USA); adenosine deaminase (Boehringer-Mannheim Biochemicals, Indianapolis, Ind., USA); Protosol, Econoflor 2, $\left[{ }^{86} \mathrm{Rb}^{+}\right] \mathrm{RbCl},\left[{ }^{3} \mathrm{H}\right]$ sucrose (New England Nuclear, Boston, Mass., USA). Tolrestat was a gift from Wyeth-Ayerst Research (Princeton, N.J., USA).

\section{Statistical analysis}

The mean $\Delta \pm$ SEM between the paired samples incubated in the absence and presence of angiotensin II or norepinephrine in each group of experiments was analysed for significance by a paired Student's $t$-test. In specific instances noted in the text and tables the difference in the mean $\Delta \pm$ SEM induced by angiotensin II or norepinephrine in two groups of paired experiments was analysed for significance by an unpaired Student's $t$-test.

\section{Results}

\section{Effects of angiotensin II (100 nmol/l)}

In paired AIM samples equilibrated and incubated with normal rabbit plasma levels of glucose $(5 \mathrm{mmol} / \mathrm{l})$ and MI $(70 \mu \mathrm{mol} / \mathrm{l})$, added angiotensin II evoked a significant increase in $\left(\mathrm{Na}^{+}, \mathrm{K}^{+}\right)$-ATPase-mediated ${ }^{86} \mathrm{Rb}^{+} / \mathrm{K}^{+}$uptake (Table 1); the mean percent increase \pm SEM was $96 \pm 13 \%$. When these experiments were repeated with adenosine deaminase $(1 \mathrm{U} / \mathrm{ml})$ added to the medium in both samples to degrade endogenously released adenosine the addition of angiotensin II had no significant effect on $\left(\mathrm{Na}^{+}, \mathrm{K}^{+}\right)$-ATPase activity (Table 1$)$. In paired AIM samples that were equilibrated and incubated in medium containing $5 \mathrm{mmol} / \mathrm{l}$ glucose, but with the medium MI omitted to inhibit MI transport and the replenishment of the adenosine-sensitive PI pool, the addition of angioten$\sin$ II also had no significant effect on $\left(\mathrm{Na}^{+}, \mathrm{K}^{+}\right)$-ATPase activity (Table 1 ).

In paired AIM samples equilibrated and incubated in medium containing $30 \mathrm{mmol} / \mathrm{l}$ glucose and $\mathrm{MI}$ at a normal 
Table 1. Effects of angiotensin II $(100 \mathrm{nmol} / \mathrm{l})$ on $\left(\mathrm{Na}^{+}, \mathrm{K}^{+}\right)$-ATPase activity in rabbit aortic intima-media (AIM)

\begin{tabular}{|c|c|c|c|c|}
\hline \multirow{2}{*}{$\begin{array}{l}\text { Incubation medium } \\
\text { Glucose (mmol/l) }\end{array}$} & \multicolumn{4}{|c|}{ Effect on $\left(\mathrm{Na}^{+}, \mathrm{K}^{+}\right)$-ATPase-mediated ${ }^{86} \mathrm{Rb}^{+} / \mathrm{K}^{+}$uptake $\left(\mu \mathrm{mol} \cdot \mathrm{g}^{-1} \cdot 20 \mathrm{~min}^{-1}\right)$} \\
\hline & $m y o$-inositol $(\mu \mathrm{mol} / \mathrm{l})$ & Mean $\triangle \pm$ SEM & $n$ & $p$ \\
\hline 5 & 70 & $+1.61 \pm 0.15^{\mathrm{a}}$ & (15) & $<0.001$ \\
\hline 5 & 70 & $+0.43 \pm 0.33$ & (10) & NS \\
\hline 5 & None & $+0.46 \pm 0.23$ & (9) & NS \\
\hline 30 & 70 & $+0.21 \pm 0.28$ & (16) & NS \\
\hline \multicolumn{5}{|c|}{+ tolrestat $(10 \mu \mathrm{mol} / \mathrm{ml})$} \\
\hline 30 & 70 & $+1.46 \pm 0.22^{\mathrm{a}}$ & (10) & $<0.001$ \\
\hline
\end{tabular}

Values are the mean difference \pm SEM in $\left(\mathrm{Na}^{+}, \mathrm{K}^{\circ}\right)$-ATPase-mediated ${ }^{86} \mathrm{Rb}^{+} / \mathrm{K}^{+}$uptake in paired AIM samples from the same aorta incubated in the absence and presence of angiatensin $\mathrm{II}(100 \mu \mathrm{mol} / \mathrm{l})$ for $20 \mathrm{~min}$. The paired AIM samples were equilibrated $(30 \mathrm{~min}$ ), pre-incubated $(10 \mathrm{~min})$, and incubated $(20 \mathrm{~min})$ in Krebs-Henseleit bicarbonate buffer, $\mathrm{pH} 7.4$ at $37^{\circ} \mathrm{C}$, gas phase $5 \% \mathrm{CO}_{2} /$ air that contained $9 \%$ dextran (average mol. wt. 70,000), and glucose and myo-

plasma level $(70 \mu \mathrm{mol} / \mathrm{l})$, added angiotensin II had no significant effect on $\left(\mathrm{Na}^{+}, \mathrm{K}^{+}\right)$-ATPase activity (Table 1$)$. However, when these experiments were repeated with the medium MI level raised to $500 \mu \mathrm{mol} / \mathrm{l}$ the addition of angiotensin II evoked a significant increase in $\left(\mathrm{Na}^{+}, \mathrm{K}^{+}\right)$ATPase-mediated ${ }^{86} \mathrm{Rb}^{+} / \mathrm{K}^{+}$uptake, and the magnitude of this effect was not significantly different from that observed in AIM incubated with normal plasma levels of glucose and MI (Table 1). Angiotensin II evoked a significant increase in $\left(\mathrm{Na}^{+}, \mathrm{K}^{+}\right)$-ATPase activity in AIM equilibrated and incubated in medium containing $30 \mathrm{mmol} / \mathrm{l}$ glucose and MI at a normal plasma level when an aldose reductase inhibitor, tolrestat $(10 \mu \mathrm{mol} / \mathrm{l})$, was added to both paired samples (Table 1); the magnitude of this effect was not significantly different from that observed in AIM incubated with normal plasma levels of glucose and MI (Table 1).

\section{Effects of norepinephrine (1 $\mu m o l l)$}

Norepinephrine evoked a significant increase in $\left(\mathrm{Na}^{+}\right.$, $\mathrm{K}^{+}$)-ATPase activity in AIM equilibrated and incubated with normal plasma levels of glucose and MI (Table 2); the mean percent increase \pm SEM was $96 \pm 26 \%$. When these experiments were repeated with adenosine deaminase $(1 \mathrm{U} / \mathrm{ml})$ added to the medium the addition of norepinephrine caused no significant change in $\left(\mathrm{Na}^{+}, \mathrm{K}^{+}\right)$ATPase activity (Table 2). Norepinephrine also had no significant effect on $\left(\mathrm{Na}^{+}, \mathrm{K}^{+}\right)$-ATPase activity in AIM equilibrated and incubated with $5 \mathrm{mmol} / \mathrm{l}$ glucose when MI was omitted from the medium (Table 2).

Norepinephrine caused no significant change in $\left(\mathrm{Na}^{+}\right.$, $\mathrm{K}^{+}$)-ATPase activity when added to AIM equilibrated and incubated with $30 \mathrm{mmol} / \mathrm{l}$ glucose and $\mathrm{MI}$ in a normal plasma level (Table 2). However, in AIM equilibrated and incubated with $30 \mathrm{mmol} / 1$ glucose the addition of norepinephrine did evoke significant increases in $\left(\mathrm{Na}^{+}, \mathrm{K}^{+}\right)$ATPase activity when the MI content of the medium was raised to $500 \mu \mathrm{mol} / \mathrm{l}$ or when the MI content remained at inositol in the concentrations noted in the table. In specific experiments adenosine deaminase or tolrestat was added to the medium in both paired samples during the equilibration, pre-incubation, and incubation. $p$ was determined by a paired Student's $t$-test analysis. a The magnitudes of these effects were not significantly different from each other when analysed by an unpaired Student's $t$-test

$70 \mu \mathrm{mol} / \mathrm{l}$ and tolrestat $(10 \mu \mathrm{mol} / \mathrm{l})$ was added to the medium (Table 2); the magnitudes of these effects were not significantly different from those observed in AIM incubated with normal plasma levels of glucose and MI (Table 2).

\section{Discussion}

Hyperglycaemia decreases $\left(\mathrm{Na}^{-}, \mathrm{K}^{+}\right)$-ATPase activity and induces early functional alterations in specific organs and regions of the vascular and nervous system by a mechanism whose effects can be prevented in diabetic animals both by aldose reductase inhibitors and by raising normal plasma MI levels approximately seven-fold $[9,10,20]$; we term this the "common initiating mechanism" [9]. Recent in vitro studies of this mechanism in resting AIM demonstrated that it decreases $\left(\mathrm{Na}^{+}, \mathrm{K}^{+}\right)$-ATPase activity by inhibiting the effector arm of a novel adenosine- $\left(\mathrm{Na}^{+}, \mathrm{K}^{+}\right)$ATPase-regulatory system by which endogenously released adenosine regulates (stimulates) and normally maintains a distinct component of resting $\left(\mathrm{Na}^{+}, \mathrm{K}^{+}\right)$-ATPase activity in AIM. The present study was concerned with determining whether one of the physiological functions of this regulatory system is to stimulate an increase in $\left(\mathrm{Na}^{+}, \mathrm{K}^{+}\right)$-ATPase activity in vascular smooth muscle when resting AIM is stimulated by angiotensin II or norepinephrine to modulate the contractile response.

When resting rabbit AIM with an intact endothelium is incubated with normal plasma levels of glucose $(5 \mathrm{mmol} / \mathrm{l})$ and MI $(70 \mu \mathrm{mol} / \mathrm{)})$ in Krebs-Henseleit bicarbonate buffer containing $9 \%$ dextran, it maintains a stable rate of $\left(\mathrm{Na}^{+}\right.$, $\mathrm{K}^{+}$)-ATPase activity, (comprised of two distinct components), that is responsible for a major fraction of the energy utilization of the tissue [11-13]. Under these conditions the addition of angiotensin II $(100 \mathrm{nmol} / \mathrm{l})$ or of norepinephrine $(1 \mu \mathrm{mol} / 1)$ in a concentration known to induce contraction in rabbit aorta [21] evoked a marked increase in $\left(\mathrm{Na}^{+}, \mathrm{K}^{+}\right)$-ATPase activity. The addition of angiotensin II or norepinephrine had no significant effect on 
Table 2. Effects of norepinephrine $(1 \mu \mathrm{mol} / \mathrm{l})$ on $\left(\mathrm{Na}^{+}, \mathrm{K}^{+}\right)$-ATPase activity in rabbit aortic intima-media (AIM)

\begin{tabular}{|c|c|c|c|c|}
\hline \multirow{2}{*}{$\begin{array}{l}\text { Incubation medium } \\
\text { Glucose }(\mathrm{mmol} / \mathrm{l})\end{array}$} & \multicolumn{4}{|c|}{ Effects on $\left(\mathrm{Na}^{+}, \mathrm{K}^{+}\right)$-ATPase-mediated ${ }^{86} \mathrm{Rb}^{+} / \mathrm{K}^{+}$uptake $\left(\mu \mathrm{mol} \cdot \mathrm{g}^{-1} \cdot 20 \mathrm{~min}^{-1}\right)$} \\
\hline & myo-inositol $(\mu \mathrm{mol} / 1)$ & Mean $\triangle \pm$ SEM & $n$ & $p$ \\
\hline 5 & 70 & $+1.52 \pm 0.30^{\mathrm{a}}$ & $(10)$ & $<0.01$ \\
\hline 5 & 70 & $+0.38 \pm 0.26$ & (9) & NS \\
\hline 5 & None & $+0.56 \pm 0.24$ & (9) & NS \\
\hline 30 & 70 & $+0.13 \pm 0.14$ & (8) & NS \\
\hline \multicolumn{5}{|l|}{+ tolrestat $(10 \mu \mathrm{mol} / \mathrm{l})$} \\
\hline 30 & 70 & $+1.10 \pm 0.32^{\mathrm{a}}$ & (8) & $<0.05$ \\
\hline
\end{tabular}

Values are the mean difference \pm SEM in $\left(\mathrm{Na}^{+}, \mathrm{K}^{+}\right)$-ATPase-mediated ${ }^{86} \mathrm{Rb}^{+} / \mathrm{K}^{+}$uptake in paired $\mathrm{AIM}$ samples incubated in the absence and presence of norepinephrine $(1 \mu \mathrm{mol} / \mathrm{l})$ for $20 \mathrm{~min}$. The experiments were performed as described in the legend for Table 1. In the experiments in which adenosine deaminase or tolrestat was

$\left(\mathrm{Na}^{+}, \mathrm{K}^{+}\right)$-ATPase activity when adenosine deaminase $(1 \mathrm{U} / \mathrm{ml})$ was added to the medium to degrade endogenously released adenosine, which is a standard means of determining whether a biological effect is dependent upon endogenously released adenosine [22]. The addition of angiotensin II or norepinephrine also had no significant effect on $\left(\mathrm{Na}^{+}, \mathrm{K}^{+}\right)$-ATPase activity when the MI was omitted from the medium to inhibit MI uptake and selectively inhibit the replenishment of the adenosine-sensitive PI pool $[12,13]$. Previous studies demonstrated that in AIM incubated with $5 \mathrm{mmol} / \mathrm{l}$ glucose the omission of MI from the medium at a normal plasma level or the addition of a competitive inhibitor of MI transport selectively inhibits the replenishment of the adenosine-sensitive PI pool and the adenosine-stimulated component of resting ( $\mathrm{Na}^{*}$, $\mathrm{K}^{+}$)ATPase activity; under these conditions the ability of specific adenosine analogues to stimulate $\left(\mathrm{Na}^{+}, \mathrm{K}^{+}\right)$ATPase activity in AIM is also inhibited $[12,13]$. Although MI in a normal plasma level in the medium is required to demonstrate the effect of endogenously released adenosine on $\left(\mathrm{Na}^{+}, \mathrm{K}^{+}\right)$-ATPase activity in $\mathrm{AIM}$, there is no requirement for $\mathrm{MI}$ in the medium to demonstrate angiotensin II or norepinephrine-induced contraction in rabbit aorta [23]. These observations indicate that angiotensin II or norepinephrine stimulation of resting AIM normally evokes a marked adenosine-stimulated increase in $\left(\mathrm{Na}^{+}, \mathrm{K}^{+}\right)$-ATPase activity that is mediated through the novel adenosine- $\left(\mathrm{Na}^{+}, \mathrm{K}^{+}\right)$-ATPase regulatory system. One can safely assume that the marked increases in total $\left(\mathrm{Na}^{+}, \mathrm{K}^{+}\right)$-ATPase activity of AIM that were observed primarily reflected adenosine-stimulated increases in vascular smooth muscle $\left(\mathrm{Na}^{+}, \mathrm{K}^{+}\right)$-ATPase activity, because the mass of vascular smooth muscle cells in AIM is much greater than that of endothelial cells.

Stimulation of increased electrogenic $\left(\mathrm{Na}^{+}, \mathrm{K}^{+}\right)$-ATPase activity in vascular smooth muscle is a vasodilatory mechanism, which modulates the component of vascular smooth muscle contraction that is dependent on membrane depolarization $[7,8,24]$. This is the distinctive vasodilatory mechanism of an endothelium-derived hyperpolarizing factor (or factors) of unknown structure, which plays a role in the modulation of vasoconstriction in ar- added to the medium, it was present in both paired AIM samples during the equilibration, pre-incubation, and incubation. $p$ was determined by a paired Student's $t$-test analysis.

a The magnitudes of these effects were not significantly different from each other when analysed by an unpaired Student's $t$-test

teries that is distinct from that of nitric oxide [7,8]. Adenosine is a vasodilator in aorta and most other arteries and resistance arterioles outside of the kidney and placenta, and it has a direct vasodilatory effect in vascular smooth muscle [15]. Vasodilatory effects of adenosine cannot be attributed solely or primarily to $\mathrm{A}_{2}$ receptors that stimulate adenylate cyclase in vascular smooth muscle and the existence of some other vasodilatory mechanism has been postulated [15]. The observation that adenosine is the endogenously released vasodilator that stimulates the increase in $\left(\mathrm{Na}^{+}, \mathrm{K}^{+}\right)$-ATPase activity in AIM that occurs in response to stimulation by angiotensin II or norepinephrine supports the inference that adenosine normally modulates the contractile responses to these vasoconstrictors in aorta, and presumably some other vessels, by stimulating increased electrogenic $\left(\mathrm{Na}^{+}, \mathrm{K}^{+}\right)$-ATPase activity in vascular smooth muscle.

In resting AIM provided with MI at a normal plasma level in the medium, raising the glucose level from 5 to $10 \mathrm{mmol} / 1$ or to $30 \mathrm{mmol} / 1$ during a 30 -min equilibration and 30-min incubation selectively inhibits the adenosinestimulated component of $\left(\mathrm{Na}^{+}, \mathrm{K}^{+}\right)$-ATPase activity; the ability of specific adenosine analogues (e.g. 2-chloroadenosine) to stimulate $\left(\mathrm{Na}^{+}, \mathrm{K}^{+}\right)$-ATPase activity is also lost $[11,12]$. The effects of endogenously released adenosine and of 2-chloroadenosine on $\left(\mathrm{Na}^{+}, \mathrm{K}^{+}\right)$-ATPase activity are preserved in AIM exposed to $30 \mathrm{mmol} / \mathrm{l}$ glucose when the MI content of the medium is raised from 70 to $500 \mu \mathrm{mol} / 1$ or when an aldose reductase inhibitor (tolrestat $10 \mu \mathrm{mol} / \mathrm{l}$ ) is added, because the replenishment of the adenosine-sensitive PI pool is not inhibited under these conditions [11, 12]. Angiotensin II and norepinephrine did not evoke significant changes in $\left(\mathrm{Na}^{+}, \mathrm{K}^{+}\right)$ATPase activity in AIM equilibrated and incubated with $30 \mathrm{mmol} / \mathrm{l}$ glucose and MI at a normal plasma level. However, when an aldose reductase inhibitor (tolrestat $10 \mu \mathrm{mol} / \mathrm{l}$ ) was added or when the MI content of the medium was raised to $500 \mu \mathrm{mol} / \mathrm{l}$, angiotensin II and norepinephrine evoked significant increases in $\left(\mathrm{Na}^{+}, \mathrm{K}^{+}\right)$ATPase activity, whose magnitudes were similar to those evoked in AIM when incubated with normal plasma levels of glucose and MI. These observations demonstrate that 
activating the "common initiating mechanism" in AIM inhibits the adenosine-stimulated increases in $\left(\mathrm{Na}^{+}, \mathrm{K}^{+}\right)$ATPase activity that normally play a role in the modulation of the responses to angiotensin II and norepinephrine. They indicate the existence of a mechanism by which hyperglycaemia could induce the increased vasoconstrictive responses to angiotensin II and norepinephrine that are observed in some arteries and resistance arterioles in diabetic states, including those in which hyperinsulinaemia is absent [1-6].

Hyperglycaemia is known to act through the "common initiating mechanism" to cause diverse early derangements in vascular regulation in diabetic states $[9,20,25$, 26]. Our observations provide a framework for efforts to understand the pathogenesis of these derangements, whose application requires attention to the regional differences in vascular regulation. They indicate that in blood vessels in which hyperglycaemia activates the "common initiating mechanism" its potential effects are not restricted to those resulting from a chronic reduction in $\left(\mathrm{Na}^{+}, \mathrm{K}^{+}\right)$-ATPase activity in the affected cells, but also include effects resulting from the loss of the acute autoregulatory effects that are normally mediated through the adenosine $\left(\mathrm{Na}^{+}, \mathrm{K}^{+}\right)$-ATPase regulatory system in that region of the vascular system. The latter could include altered responses to specific vasoactive hormones and neurotransmitters and derangements in the autoregulation of regional blood flow induced by the loss of one of the vasodilatory mechanisms of adenosine.

Acknowledgements. The expert technical assistance of Mr. C. Young, Mr. S. Shin and Ms. A. Guise is gratefully acknowledged. This project was supported by a grant from the American Diabetes Association and support provided by the Ware Foundation.

\section{References}

1. Drury PL, Smith GM, Ferriss JB (1984) Increased vasopressor responsiveness to angiotensin II in type 1 (insulin-dependent) diabetic patients without complications. Diabetologia 27: 174179

2. Weidman P, Berreta Picolli C, Keusch G et al. (1979) Sodiumvolume factor, cardiovascular reactivity and hypotensive mechanism of diuretic therapy in mild hypertension associated with diabetes mellitus. Am J Med 67: 779-784

3. Brody MJ, Dixon RL (1964) Vascular reactivity in experimental diabetes mellitus. Circ Res 14: 494-501

4. Scarborough NL, Carrier GO (1983) Increased alpha-2 adrenoreceptor mediated vascular contraction in diabetic rats. $\mathrm{J}$ Auton Pharmacol 3: 177-183

5. Hill MA, Larkins RG (1989) Altered microvascular reactivity in streptozotocin-induced diabetes in rats. Am $\mathbf{J}$ Physiol 257: $\mathrm{H} 1438-\mathrm{H} 1445$

6. Abiru T, Kamata K, Miyata N, Kasuya Y (1990) Differences in vascular responses to vasoactive agents of basilar artery and aorta from rabbits with alloxan-induced diabetes. Can J Physiol Pharmacol 68: 882-888

7. Vanhoutte PM (1988) The endothelium - modulator of vascular smooth-muscle tone. N Engl J Med 319:512-513

8. Hoeffner U, Feletou M, Flavahan NA, Vanhoutte P (1989) Canine arteries release two different endothelium-derived relaxing factors. Am J Physiol 257: H330-H333
9. Winegrad AI (1987) Does a common mechanism induce the diverse complications of diabetes? Diabetes 36: 396-406

10. Greene DA, Lattimer SA, Sima AAF (1987) Sorbitol, phosphoinositides, and sodium-potassium ATPase in the pathogenesis of diabetic complications. N Engl J Med 316: 599-606

11. Simmons DA, Winegrad AI (1989) Mechanism of glucose-induced $\left(\mathrm{Na}^{+}, \mathrm{K}^{+}\right)$-ATPase inhibition in aortic wall of rabbits. Diabetologia 32: 402-408

12. Simmons DA, Winegrad AI (1991) Elevated extracellular glucose inhibits an adenosine- $\left(\mathrm{Na}^{+}, \mathrm{K}^{+}\right)$-ATPase regulatory system in rabbit aortic wall. Diabetologia 34: 157-163

13. Simmons DA, Kern EFO, Winegrad AI, Martin DB (1986) Basal phosphatidylinositol turnover controls aortic $\left(\mathrm{Na}^{+}, \mathrm{K}^{+}\right)$-ATPase activity. J Clin Invest 51:3114-3123

14 . Newby AC (1984) Adenosine and the concept of retaliatory metabolites. Trends Biol Sci 9: 42-44

15. Olsson RA, Pearson JD (1990) Cardiovascular purinoceptors. Phys Rev 70: 761-845

16. Berne RM, Knabb RM, Ely RW, Rubio R (1983) Adenosine in the local regulation of blood flow: a brief overview. Fed Proc 42: 3136-3142

17. Morrison AD, Berwick L, Orci L, Winegrad AI (1976) Morphology and metabolism of an aortic intima-media preparation in which an intact endothelium is preserved. J Clin Invest 57: 650 660

18. Morrison AD, Orci L, Berwick L, Winegrad AI (1977) The effects of anoxia on the morphology and composite metabolism of the intact aortic intima-media preparation. J Clin Invest 59: $1027-1037$

19. Krebs HA, Henseleit K (1932) Untersuchungen über die Harnstoffbildung im Tierkörper. Hooppe-Seylers Z Physiol Chem 210: 33-36

20. Pugliese G, Tilton RG, Speedy A et al. (1990) Modulation of hemodynamic and vascular filtration changes in diabetic rats by dietary myo-inositol. Diabetes 39: 312-322

21. Takuwa Y, Rasmussen H (1987) Measurement of cytoplasmic free $\mathrm{Ca}^{2+}$ concentration in rabbit aorta using the photoprotein, aequorin. J Clin Invest 80: 248-257

22. Daly JW (1982) Adenosine receptors: targets for future drugs. J Med Chem 25: 197-207

23. Campbell MD, Deth RC, Payne RA, Honeyman TW (1985) Phosphoinositide hydrolysis is correlated with agonist-induced calcium flux and contraction in the rabbit aorta. Eur J Pharmacol 116: $129-136$

24. Webb RC, Lockette WE, Vanhoutte RM, Bohr DF (1981) Sodium, potassium-adenosinetriphosphatase and vasodilatation. In: Vanhoutte PM, Leusen I (eds) Vasodilatation. Raven Press, New York, pp 319-330

25. Goldfarb S, Simmons DA, Kern EFO (1986) Amelioration of glomerular hyperfiltration in acute experimental diabetes by dietary myo-inositol supplementation and aldose reductase inhibition. Trans Assoc Am Phys 99: 67-72

26. Perlmutter J, Jacobs J, Ziyadeh F et al. (1989) Reduced renal vasoconstrictive response to adenosine and reversal by aldose reductase inhibition in acute experimental diabetes. Clin Res 37: 583 (Abstract)

Received: 29 November 1991

and in revised form: 21 April 1992

Dr. D. A. Simmons

Cox Institute

University of Pennsylvania

Philadelphia, PA 19104-6056

USA 